
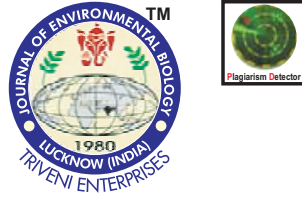

\title{
Growth and productivity of potato (cv. Kufri Jyoti) and soil nutrient status as influenced by different nutrient management in new alluvial zone of West Bengal
}

Authors Info

P. Irungbam ${ }^{1 *}$, M. Pramanick ${ }^{1}$ and T. Sanahanbi Devi ${ }^{2}$

${ }^{1}$ Department of Agronomy, Faculty of Agriculture, Bidhan Chandra

Krishi Vishwavidalaya, Mohanpur-741 252, India

${ }^{2}$ Department of Soil Science and Agricultural Chemistry, College of Agriculture, Central Agricultural University, Imphal West, Lamphelpat - 795 004, India

*Corresponding Author Email : priyanka.irungbam@gmail.com

Key words

Farmyard manure Nutrient management Potato cv. Kufri Jyoti Soil nutrient

Publication Info

Paper received : 12.07 .2016

Revised received : 27.01.2017

Re-revised received : 03.06.2017 Accepted : 01.07.2017

\section{Abstract}

Aim : A field experiment was conducted during winter season to study the effect of different nutrient management on growth and productivity of potato (cv. Kufri Jyoti) and soil nutrient status in new alluvial zone of WestBengal.

Methodology : The experimental site is located at Regional Research Station, New Alluvial Zone of Bidhan Chandra Krishi Vishwavidalaya, Gayeshpur, Nadia, West Bengal at an altitude of $9.75 \mathrm{~m}$ amsl. The experiment was laid out in a randomized block design with three replications and consisted of eight different treatments. Observations on growth and yield attributes were recorded and soil nutrient analysis was carried out before planting and after harvest of potato.

Results :The highest values of plant height $(48.47 \mathrm{~cm})$, dry matter accumulation $\left(686.70 \mathrm{gm}^{-2}\right)$ and crop growth rate $\left(7.78 \mathrm{gm}^{-2}\right.$ day $\left.^{-1}\right)$ was observed in the treatment $\left(T_{7}\right)$ receiving $100 \%$ recommended dose of fertilizer, which was statistically at par with integrated nutrient management receiving $50 \% \mathrm{RDF}+50 \% \mathrm{~N}$ as farmyard manure. Similarly, $100 \% \operatorname{RDF}\left(\mathrm{T}_{7}\right)$ gave better yield parameters like dry weight of tuber $(547.95$ $\left.\mathrm{gm}^{-2}\right)$, number of tubers per hill (5.57), tuber bulking rate $\left(9.33 \mathrm{gm}^{-2}\right)$ and maximum tuber yield of 22.19 tha $^{-1}$ which was also statistically at par with integrated nutrient management receiving $50 \% \mathrm{RDF}+50 \% \mathrm{~N}$ as farmyard manure with tuber yield of $21.72 \mathrm{t} \mathrm{ha}^{-1}$. However, organic nutrient management containing $1 / 3^{\text {rd }}$ recommended $\mathrm{N}$ each from farmyard manure, vermicompost, neemcake along with rock phosphate, phosphorus solubilizing bacteria and Azotobacter showed significantly highest organic carbon content, total nitrogen, available phosphorus and available potassium content in soil among the various organic treatments followed by integrated nutrient management.

Interpretation : The growth and yield attributes of potato were found to be significantly improved in the treatment receiving $100 \%$ recommended dose of fertilizer and $50 \%$ RDF $+50 \% \mathrm{~N}$ as farmyard manure, respectively. However, all the organic based treatments showed significant improvement in soil nutrient status like organic carbon, total nitrogen, available phosphorus and available potassium.
Selection of best nutrient management package for potato

Eight treatments replicated thrice in a randomized block design

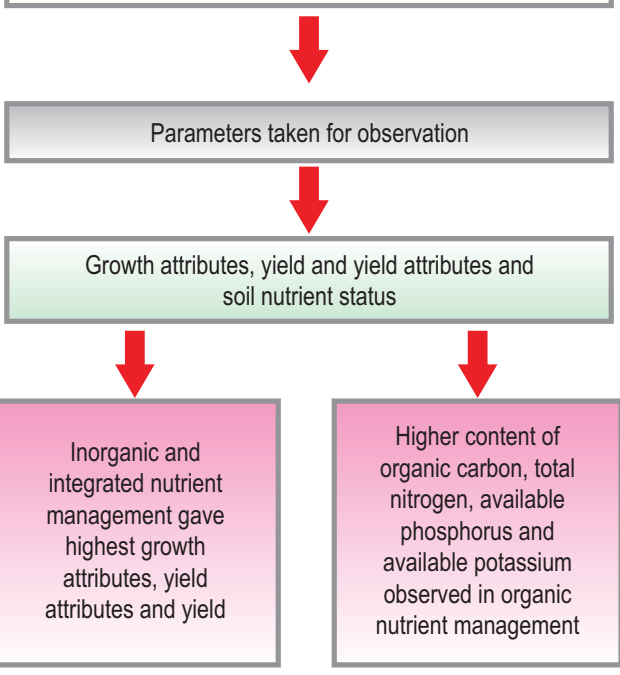




\section{Introduction}

Potato (Solanum tuberosum) is the world's fourth most economically important staple food crop in many countries due to its yield potential and high nutritive value. The tuber contains about $20.6 \%$ carbohydrates, $2.1 \%$ protein, $0.1 \%$ fat, $1.1 \%$ crude fibre and $0.9 \%$ ash. It also contains a good amount of essential amino acids like leucine, tryptophan and isoleucine (Khurana and Naik, 2003). Fertilizer requirement of potato is high as compared to cereal crops and is considered heavy nutrients feeder. It responds well to applied fertilizers and gives good yield per unit area and time. Thus, chemical fertilizers are the main source of nutrients for potato cropping. However, continuous dependence on chemical fertilizers causes nutritional imbalance and adverse effects on physico-chemical and biological properties of the soil (Arya and Roy, 2009). Organic farming is the need of the day that avoids depletion of soil organic matter and plant nutrients (Gaur, 2001; Govindakrishnan and Kushwah, 2003). The beneficial effects of organic manures are manifested through increase in soil organic matter and humus over the period. Soil organic matter and humus acts in several ways; it serves as slow release source of plant nutrients to the crops and increases water holding capacity to maintain the water regime of the soil and acts as a buffer against change in soil pH (Upadhayay and Singh, 2003). However, under present day's condition, it is neither possible nor feasible to replace chemical fertilizers completely to sustain present high level of crop production to meet food grain supply for the ever increasing population (Tarafdar et al., 2008). Integrated nutrient management involving combination of organic manure and fertilizers is an essential tool for balanced fertilization and sustainability of crop production on long term basis (Hegde and Dwivedi, 1993). Fertilizers being a costly input, phosphorus solubilizing bacteria could supplement the nutrient requirement of potato crop, especially phosphorus thereby boosting the yield (Praharaj et al., 2002). Integrated use of nutrients from chemical, organic and biofertilizers is the most efficient way to supply plant nutrients for sustained crop productivity and improved soil fertility (Singh et al., 2002). Biofertilizers like phosphorus solubilizing bacteria and Azotobacter may be useful for improving phosphorus and nitrogen nutrition in potato. These evidences indicate that the use of synthetic fertilizer in combination with organic manures could be a key factor for achieving and maintaining high productivity of potato. Therefore, a field experiment was carried out to study the growth and productivity of potato (cv.Kufri Jyoti) and soil nutrient status like organic carbon, total nitrogen, available phosphorus and available potassium as influenced by different nutrient management in new alluvial zone of West Bengal.

\section{Materials and Methods}

A field experiment was conducted at Regional Research Station of Bidhan Chandra Krishi Vishwavidalaya, Gayeshpur, Nadia, West Bengal. The soil of the experimental field was sandy clay loam (39.2\% silt, $29.0 \%$ sand and $31.8 \%$ clay) with good drainage facilities and medium soil fertility having $\mathrm{pH} 7.3$, organic carbon $0.65 \%$, total nitrogen $0.060 \%$ and available phosphorus and potassium of $16.16 \mathrm{~kg} \mathrm{ha}^{-1}$ and $163.51 \mathrm{~kg} \mathrm{ha}^{-1}$, respectively. The experiment was laid out in a randomized block design with three replications and consisted of eight different treatments which include one integrated nutrient management $\mathrm{T}_{1}: 50 \% \mathrm{RDF}+$ $50 \% \mathrm{~N}$ as $\mathrm{FYM}$; five organic nutrient management, namely $\mathrm{T}_{2}$ : $1 / 3^{\text {rd }}$ recommended $\mathrm{N}$ each from $\mathrm{FYM}$, vermicompost, neemcake; $\mathrm{T}_{3}: \mathrm{T}_{2}+$ Intercropping (potato+ coriander- 1:1); $\mathrm{T}_{4}: \mathrm{T}_{2}+$ rice straw mulch for weed management; $\mathrm{T}_{5}: 50 \% \mathrm{~N}$ as $\mathrm{FYM}+$ Rock phosphate + PSB + Azotobacter, $\mathrm{T}_{6}: \mathrm{T}_{2}+$ Rock phosphate + PSB + Azotobacter; one purely inorganic nutrient treatment, $\mathrm{T}_{7}: 100 \%$ RDF and $T_{8}$ : Control (without manures and fertilizers). The recommended dose of fertilizer was 100:150:150 kg N: $\mathrm{P}_{2} \mathrm{O}_{5}: \mathrm{K}_{2} \mathrm{O}$ per hectare and the source of fertilizers used were urea for nitrogen, single super phosphate for phosphorus and muriate of potash for potassium. Three fourth of nitrogen complete dose of $\mathrm{P}_{2} \mathrm{O}_{5}$ and $\mathrm{K}_{2} \mathrm{O}_{5}$ were applied before planting, while the remaining one fourth of nitrogen was applied during earthing up for the treatments receiving inorganic fertilizers. Organic manures like farmyard manure, vermicompost and neemcake were applied at the final land preparation as per treatments. Applied farry yard manure contained $0.63 \% \mathrm{~N}, 0.25 \% \mathrm{P}_{2} \mathrm{O}_{5}$ and $0.54 \% \mathrm{~K}_{2} \mathrm{O}$, whereas neemcake contained $5.20 \% \mathrm{~N}, 1.0 \% \mathrm{P}_{2} \mathrm{O}_{5}$ and $1.4 \% \mathrm{~K}_{2} \mathrm{O}$ and vermicompost contained $\mathrm{N}, \mathrm{P}_{2} \mathrm{O}_{5}$ and $\mathrm{K}_{2} \mathrm{O}$ in tune of $1.92 \%$, $0.70 \%$ and $1.4 \%$, respectively. Rock phosphate was mixed thoroughly with PSB before applying to the field at final land preparation. Kufri Jyoti was used as the recommended variety in this experiment. Healthy tubers were cut and inoculated with Azotobacter just before planting as per the treatment. The tubers were then planted $45 \mathrm{~cm}$ apart in furrows with plant to plant spacing of $20 \mathrm{~cm}$ in the first week of December. Earthing up was done twice, first at 15-20 days after planting and second at 15 day interval, besides hand weeding was practiced when required. First irrigation was given immediately after planting tuber, and subsequently during the crop period five irrigations were given at 15 - day interval after first irrigation. The crop was harvested in the first week of March. Soil was analyzed at initial stage and after completion of the experiment to monitor the changes in nutrient status viz. organic carbon (\%), total nitrogen (\%), available phosphorus ( $\left.\mathrm{kg} \mathrm{ha}^{-1}\right)$ and potassium $\left(\mathrm{kg} \mathrm{ha}^{-1}\right)$ as per the standard methods (Jackson, 1973, Muhr et al. 1965). Growth attributes of potato were recorded at 30 - day interval from planting and yield attributes were recorded at harvest. Ten plants per plot were taken for recording growth and yield attributes. Data of different parameters were analyzed as per standard procedure at $5 \%$ probability level (Gomez and Gomez, 1984).

\section{Results and Discussion}

The plant height and dry matter accumulation increased progressively at different stages of growth and reached their peak at harvest (Table 1). Among the treatments, inorganic treatment $i$. 
e., $T_{7}$ showed highest plant height of $48.47 \mathrm{~cm}$ but remained statistically at par with $\mathrm{T}_{1}$ with $46.10 \mathrm{~cm}$, followed by treatment, $\mathrm{T}_{6}$ with $44.0 \mathrm{~cm}$. Islam et al. (2013) reported highest plant height with $100 \%$ RDF followed by combined application of poultry manure and reduced dose of recommended fertilizers. The maximum dry matter accumulation ( $686.70 \mathrm{gm}^{-2}$ ) was observed in $\mathrm{T}_{7}$, which was statistically at par with $T_{1}\left(647.12 \mathrm{gm}^{-2}\right)$ at the time of harvest i.e., 90 days after planting, followed by $\mathrm{T}_{6}\left(595.70 \mathrm{gm}^{-2}\right)$. Different nutrient management like inorganic, integrated and organic nutrient treatments caused significant variation in crop growth rate of potato where higher magnitude of crop growth rate was recorded 30-60 days after planting with inorganic nutrient management $T_{7}$ to the tune of $14.87 \mathrm{gm}^{-2} \mathrm{day}^{-1}$ and $7.78 \mathrm{gm}^{-2} \mathrm{day}^{-1}$ at 60-90 days after planting, but it was found to be statistically at par with $T_{1}$, followed by $T_{6}$. The lowest values of plant height, dry matter accumulation and crop growth rate was observed in control. Najm et al. (2010) also observed the beneficial effect of integrated nutrient management on the growth parameters of potato like plant height, leaf area index and crop growth rate. The increased value in growth characters might be due to the combined effect of organic and inorganic fertilizers on increased nutrient availability resulting in better nutrient absorption and growth of crops. Moreover, inorganic fertilizer has an immediate effect and its nutrient release is often well synchronized with plant growth. Application of 75\% RDF through synthetic fertilizers and $25 \%$ RDN through FYM was recorded more remunerative for sustainable production of potato in the hills of Meghalaya (Yadav etal., 2014).

Dry weight of potato was found to increase progressively from 50 days after planting and reached maximum value at 90 days after planting (Table 2). The highest dry weight of tuber was recorded in $T_{7}\left(547.95 \mathrm{gm}^{-2}\right)$, followed by $T_{1}\left(520.34 \mathrm{gm}^{-2}\right) 90$ days after planting. Among the organic treatments, $\mathrm{T}_{6}$ recorded higher tuber dry weight of $484.52 \mathrm{gm}^{-2}$, followed by $\mathrm{T}_{4}\left(471.44 \mathrm{gm}^{-2}\right)$ at 90 days after planting. However, the lowest dry weight of tubers was obtained in $T_{8}\left(252.55 \mathrm{gm}^{-2}\right)$, followed by $T_{3}$ treatment $\left(367.77 \mathrm{gm}^{-2}\right)$, which might be due to the competitive effect of potato with coriander on crop growth resulting in lower tuber weight.

Table 1 : Effect of different nutrient management on growth attributes of potato (cv. Kufri Jyoti) at various growth stages

\begin{tabular}{|c|c|c|c|c|c|c|c|c|}
\hline \multirow[t]{2}{*}{ Treatments } & \multicolumn{3}{|c|}{$\begin{array}{l}\text { Plant height } \\
(\mathrm{cm})\end{array}$} & \multicolumn{3}{|c|}{$\begin{array}{l}\text { Dry matter accumulation } \\
\left(\mathrm{gm}^{-2}\right)\end{array}$} & \multicolumn{2}{|c|}{$\begin{array}{l}\text { Crop growth rate } \\
\left(\mathrm{gm}^{-2} \text { day }^{-1}\right)\end{array}$} \\
\hline & 30 DAP & 60 DAP & Harvest & 30 DAP & 60 DAP & Harvest & 30-60 DAP & $60-90$ DAP \\
\hline $\mathrm{T}_{1}$ & 14.51 & 39.54 & 46.10 & 34.63 & 425.15 & 647.12 & 13.02 & 7.40 \\
\hline $\mathrm{T}_{2}$ & 12.78 & 36.36 & 42.37 & 18.53 & 327.64 & 448.40 & 10.75 & 4.03 \\
\hline $\mathrm{T}_{3}$ & 11.13 & 34.64 & 41.70 & 15.14 & 290.43 & 379.38 & 9.40 & 2.97 \\
\hline $\mathrm{T}_{4}$ & 12.83 & 36.46 & 43.60 & 21.92 & 356.05 & 485.74 & 11.47 & 4.32 \\
\hline $\mathrm{T}_{5}$ & 12.05 & 35.95 & 42.27 & 21.29 & 311.75 & 452.99 & 9.68 & 4.71 \\
\hline $\mathrm{T}_{6}$ & 13.43 & 38.11 & 44.00 & 25.45 & 389.23 & 595.70 & 12.13 & 6.88 \\
\hline $\mathrm{T}_{7}$ & 15.10 & 41.91 & 48.47 & 37.29 & 453.25 & 686.70 & 14.87 & 7.78 \\
\hline $\mathrm{T}_{8}$ & 10.13 & 30.91 & 37.07 & 13.42 & 242.45 & 322.24 & 7.63 & 2.66 \\
\hline S.Em \pm & 0.62 & 0.64 & 1.12 & 1.76 & 21.36 & 28.13 & 0.80 & 1.13 \\
\hline$C D(p=0.05)$ & 1.88 & 1.94 & 3.41 & 5.33 & 64.78 & 85.32 & 2.43 & 3.42 \\
\hline
\end{tabular}

Table 2 : Effect of different nutrient managements on yield attributes and yield of potato cv. Kufri Jyoti

\begin{tabular}{|c|c|c|c|c|c|c|c|}
\hline \multirow[t]{2}{*}{ Treatments } & \multicolumn{3}{|c|}{$\begin{array}{l}\text { Dry weight of } \\
\text { tubers }\left(\mathrm{gm}^{-2}\right)\end{array}$} & \multicolumn{2}{|c|}{$\begin{array}{l}\text { Tuber bulking } \\
\text { rate }\left(\mathrm{gm}^{-2} \text { day }{ }^{-1}\right)\end{array}$} & \multirow[t]{2}{*}{$\begin{array}{l}\text { Tubers/ hill } \\
\text { (Numbers) }\end{array}$} & \multirow[t]{2}{*}{$\begin{array}{l}\text { Tuber yield } \\
\left(\text { tha }^{-1}\right)\end{array}$} \\
\hline & 50 DAP & 70 DAP & Harvest & 50-70 DAP & $70-90$ DAP & & \\
\hline $\mathrm{T}_{1}$ & 163.92 & 347.28 & 520.34 & 9.17 & 8.65 & 5.35 & 21.72 \\
\hline $\mathrm{T}_{2}$ & 141.26 & 288.82 & 431.53 & 7.38 & 7.14 & 4.55 & 18.84 \\
\hline $\mathrm{T}_{3}$ & 113.21 & 244.03 & 367.77 & 6.54 & 6.19 & 4.18 & $17.77(4.02)^{*}$ \\
\hline $\mathrm{T}_{4}$ & 147.84 & 322.03 & 471.44 & 8.71 & 7.47 & 4.53 & 19.42 \\
\hline $\mathrm{T}_{5}$ & 124.33 & 263.53 & 386.56 & 6.96 & 6.15 & 4.05 & 18.25 \\
\hline $\mathrm{T}_{6}$ & 148.77 & 331.57 & 484.52 & 9.14 & 7.65 & 4.94 & 20.04 \\
\hline $\mathrm{T}_{7}$ & 167.47 & 364.63 & 547.95 & 9.86 & 9.33 & 5.57 & 22.19 \\
\hline $\mathrm{T}_{8}$ & 62.15 & 164.92 & 252.55 & 5.14 & 4.38 & 3.07 & 10.87 \\
\hline S.Em \pm & 4.34 & 15.06 & 4.86 & 0.68 & 0.56 & 0.20 & 0.65 \\
\hline$C D(p=0.05)$ & 13.16 & 45.69 & 14.73 & 2.07 & 1.72 & 0.60 & 1.97 \\
\hline
\end{tabular}

*yield of coriander leaf in terms of potato equivalent yield 
Table 3 : Effect of integrated nutrient management on fertility status of soil at harvest of potato

\begin{tabular}{lllll}
\hline Treatments & $\begin{array}{l}\text { Organic } \\
\text { carbon } \\
(\%)\end{array}$ & $\begin{array}{l}\text { Total } \\
\text { nitrogen } \\
(\%)\end{array}$ & $\begin{array}{l}\text { Available } \\
\text { phosphorus } \\
\left(\mathbf{k g ~ h a}^{-1}\right)\end{array}$ & $\begin{array}{l}\text { Available } \\
\text { potassium } \\
\left(\mathbf{k g ~ h a}^{-1}\right)\end{array}$ \\
\hline$T_{1}$ & 0.70 & 0.068 & 18.48 & 166.60 \\
$T_{2}$ & 0.85 & 0.073 & 19.18 & 168.91 \\
$T_{3}$ & 0.79 & 0.068 & 17.01 & 157.11 \\
$T_{4}$ & 0.86 & 0.072 & 19.77 & 169.61 \\
$T_{5}$ & 0.89 & 0.070 & 18.87 & 167.25 \\
$T_{6}$ & 0.91 & 0.075 & 20.58 & 174.24 \\
$T_{7}$ & 0.68 & 0.063 & 17.89 & 171.15 \\
$T_{8}$ & 0.64 & 0.051 & 12.40 & 140.75 \\
Initial & 0.65 & 0.060 & 16.16 & 163.51 \\
$S . E m \pm$ & 0.02 & 0.001 & 0.50 & 0.95 \\
$C D(p=0.05)$ & 0.05 & 0.003 & 1.51 & 2.87 \\
\hline
\end{tabular}

Significant influence on tuber bulking rate of potato due to different nutrient management was observed between $50-70$ days after planting and 70-90 days after planting (Table 2). The result revealed that tuber bulking rate was found higher at 50-70 days after planting as compared to 70-90 days after planting. maximum tuber bulking rate was observed under inorganic treatment $\mathrm{T}_{7}$ (9.86 and $9.33 \mathrm{gm}^{-2}$ day $\left.^{-1}\right)$ which was found statistically at par with integrated nutrient management $T_{1}(9.17$ and $\left.8.65 \mathrm{gm}^{-2} \mathrm{day}^{-1}\right)$ and $\mathrm{T}_{6}\left(9.14\right.$ and $\left.7.65 \mathrm{gm}^{-2} \mathrm{day}^{-1}\right)$ at 50-70 days after planting and 70-90 days after planting, respectively the lowest tuber bulking rate was observed in $\mathrm{T}_{8}$ ( 5.14 and 4.38 $\mathrm{gm}^{-2}$ day $^{-1}$ ). Mondal and Sarkar (2005) reported similar results with tuber bulking rate $\left(10.47 \mathrm{gm}^{-2} \mathrm{day}^{-1}\right)$ at $60-85$ days after planting and $9.85 \mathrm{gm}^{-2}$ day $^{-1}$ at $85-105$ days after planting when $150 \%$ RDF was applied along with enmite in potato. Better nutrition of the crop through integration of fertilizer and organic nutrients application was mainly responsible for higher tuber bulking rate, which ultimately led to high tuber productivity (Mondal, 2016).

The treatment receiving 100\% RDF $\left(T_{7}\right)$ recorded highest number of tubers per hill (5.57) which was found to be statistically at par with integrated nutrient management, $\mathrm{T}_{1}(5.35)$, followed by $\mathrm{T}_{6}$ (4.94) (Table 2). The lowest number of tubers per hill was obtained in control, $\mathrm{T}_{8}$ (3.07). The optimum growth of the plant due to favorable nutritional environment and higher uptake of nutrients by the plants might have favored significant increase in the tuber bulking rate and increased number of tubers/hill.

Tuber yield of potato also differed significantly due to different nutrient management (Table 2). Maximum tuber yield was produced under inorganic treatment, $\mathrm{T}_{7}\left(22.19 \mathrm{t} \mathrm{ha}^{-1}\right)$ which was found to be statistically at par with integrated nutrient management, $\mathrm{T}_{1}\left(21.72 \mathrm{t} \mathrm{ha}^{-1}\right)$. Among the different organic treatments, $\mathrm{T}_{6}$ produced highest yield $\left(20.04\right.$ tha $\left.^{-1}\right)$ which was statistically at par with $T_{4}, T_{2}$ and $T_{5}$ with yield of $19.42,18.84$ and 18.25 tha $^{-1}$, respectively. Lowest yield was recorded in $T_{3}\left(17.77\right.$ t ha $\left.{ }^{-1}\right)$ after $T_{8}$
(10.87 tha $\left.{ }^{-1}\right)$, which might be due to the competitive effect of potato with intercrop coriander on crop growth and due to greater uptake of nutrients by coriander. The higher tuber yield achieved in $T_{7}$ and $\mathrm{T}_{1}$ is due to improved growth attributes as a result of quick release of the nutrients in the soil and their subsequent availability to plants. The results are in conformity with the findings of Baishya et al. (2010) who observed that number of tubers/plant, mean tuber weight, marketable and total tuber yield of potato increased significantly due to the use of $100 \%$ RDF or $75 \%$ RDF $+25 \%$ RDN through farmyard manure. The yield components and tuber yield decreased gradually as the crop received higher proportion of plant nutrients through FYM. The favorable effect of integrated nutrient management and inorganic nutrient management on tuber yield of potato was also observed by Kumar et al. (2012). Fekadu Asfaw (2016) also observed that application of wood ash and farmyard manure along with $50 \%$ RDF gave maximum tuber yield which may be due to increased tuber weight, tuber girth and higher proportion of large and medium sized tuber. The results are also in conformity with Mbogo et al. (2017) who observed highest tuber yield from the treatment receiving 100\% inorganic NPK which according to him could be due to fast release of nutrients by NPK and slow release of nutrients by cattle manure. The first released nutrients especially phosphorus had a healthy influence on sprouting, root development vegetative vigour and maturing of the potato thus highest yield.

The organic based nutrient treatments showed higher organic carbon content, total nitrogen, available phosphorus and potassium content in soil in comparison with inorganic nutrient management and integrated nutrient management(Table 3).

The maximum organic carbon content was found under the organic treatment, $\mathrm{T}_{6}(0.91 \%)$ which was statistically at par with $\mathrm{T}_{5}(0.89 \%)$ and $\mathrm{T}_{4}(0.87 \%)$, followed by $\mathrm{T}_{2}$ and $\mathrm{T}_{3}$ in tune of $(0.85 \%)$ and $(0.79 \%)$, respectively. All the organic and integrated based treatments showed an increase in organic carbon content over the initial value of $0.65 \%$. Increased content of organic 
carbon in soil under organic nutrient treatments might be attributed to the application of organic matter from outside into the soil. Application of organic manure either alone or in combination with inorganic fertilizers was beneficial for improving or maintaining organic carbon pool in soil (Manna et al., 2006; Ghosh et al., 2009 and Kumar et al., 2012).

The maximum increase in total nitrogen content in soil over initial $(0.060 \%)$ was found in treatment $\mathrm{T}_{6}(0.075 \%)$, which was statistically at par with treatment $\mathrm{T}_{2}(0.073 \%)$ and $\mathrm{T}_{4}(0.072$ $\%)$ followed by $\mathrm{T}_{5}(0.070 \%), \mathrm{T}_{1}(0.068 \%)$ and $\mathrm{T}_{3}(0.068 \%)$, where $\mathrm{T}_{5}, \mathrm{~T}_{1}$ and $\mathrm{T}_{3}$ were statistically at par with each other. The percentage increase of $T_{6}, T_{2}$ and $T_{4}$ over control $T_{8}$ was $25,21.67$ and $20 \%$ respectively. Inorganic treatment $\mathrm{T}_{7}$ recorded lower nitrogen content $(0.063 \%)$ followed by control $(0.051 \%)$. Increase in total $\mathrm{N}$ content in the soil under organic nutrient management might be due to release of nitrogen after decomposition of organics and direct addition through FYM to the available pool of the soil. Besides, it is attributed to the greater multiplication of soil microbes which could convert organically bound $\mathrm{N}$ into inorganic form. Similar increase in available nitrogen in soil and better soil health due to the application of organic manure at $100 \%$ recommended dose of nitrogen through organic sources with biofertilizers (Azotobacter and PSB) was also observed by Yadav et al. (2013a). The higher nitrogen content in the treatments receiving organic manure might be due to the direct addition of nitrogen from the decomposition of organic matter which leads to mineralization of organically bound nitrogen (Jat and Singh, 2017).

Available phosphorus content in soil was found to be higher under all the organic treatments except $\mathrm{T}_{3}$, followed by integrated nutrient management $\left(T_{1}\right)$ and inorganic nutrient management $\left(T_{7}\right)$. The maximum value of available phosphorus was obtained in $\mathrm{T}_{6}\left(20.58 \mathrm{~kg} \mathrm{ha}^{-1}\right)$, which was statistically at par with $\mathrm{T}_{4}\left(19.77 \mathrm{~kg} \mathrm{ha}^{-1}\right)$ and $\mathrm{T}_{2}\left(19.18 \mathrm{~kg} \mathrm{ha}{ }^{-1}\right)$ and their percentage increase over the initial value (16.16 kg ha ${ }^{-1}$ ) was $27.35 \%$, $22.34 \%$ and $18.69 \%$, respectively. Intercrop based nutrient management treatment, $\mathrm{T}_{3}$ recorded lower phosphorus content in soil $\left(17.01 \mathrm{~kg} \mathrm{ha}^{-1}\right)$ after inorganic treatment, $T_{7}\left(17.89 \mathrm{~kg} \mathrm{ha}^{-1}\right)$ which might be due to uptake by coriander. Control treatment recorded the lowest phosphorus content (12.40 kg ha $\left.{ }^{-1}\right)$ in soil in tune of $24.21 \%$ lower than the initial. Appreciable increase in available phosphorus content of soil in the organic management treatments may be due to the influence of organic manure which could have enhanced the labile phosphorus in soil by complexing the cations like $\mathrm{Ca}, \mathrm{Mg}$ and $\mathrm{Al}$ responsible for the fixation of phosphorus. The soil-available phosphorus was slightly improved due to addition of organic manure over the initial soil value. The organic manures, on decomposition, solubilize insoluble organic phosphorus fractions through release of various organic acids, thus resulting in a significant improvement in available phosphorus status of soil (Chadha et al., 2006).
Available potassium content in soil was found to increase significantly over the initial value of $163.51 \mathrm{~kg} \mathrm{ha}^{-1}$ in all the treatments, except for intercrop based treatment, $\mathrm{T}_{3}$ and control, $\mathrm{T}_{8}$. The maximum available potassium in soil was recorded under organic treatment $T_{6}\left(174.24 \mathrm{~kg} \mathrm{ha}^{-1}\right)$, followed by inorganic treatment $\mathrm{T}_{7}\left(171.15 \mathrm{~kg} \mathrm{ha}^{-1}\right)$ and organic treatment $\mathrm{T}_{4}(169.61 \mathrm{~kg}$ $\left.\mathrm{ha}^{-1}\right)$ respectively. All the treatments gave significantly higher available potassium over control. This increase in available potassium content in soil due to addition of organic manures might be attributed to the direct addition of potassium in the available potassium pool in soil and release of potassium due to interaction of organic matter with clay (Yadav et al., 2013b). Zaman et al. (2011) also reported that farmyard manure @30 t ha ${ }^{-1}$ along with biofertilizers recorded maximum soil fertility build-up after harvest of the crop. Kushwah et al. (2005) were of similar view and reported that manures have sufficient residual effect on soil nutrient supply system. They also supply micronutrients in addition to major plant nutrients. The favorable effect of combined application of chemical fertilizer, biofertilizer and compost on soil macronutrients was also reported by Datta et al. (2009). This improvement in soil fertility is attributed to the addition of FYM and other organics which stimulated the growth and activity of microorganisms. They participate in the biological cycling of elements and transformation of the mineral compounds and thus increases the availability of nutrients in soil (Vidyavathi etal. 2011).

The results showed that inorganic nutrient management and integrated use of inorganic and organic sources of nutrients significantly improved the growth and yield of potato. Whereas organic based treatments showed significant improvement in soil nutrient status over inorganic treatment. Thus, considering the above results, it can be concluded that application of organic manures including biofertilizers either alone or in combination with inorganic fertilizer can be recommended for sustained productivity of soil and potato crop.

\section{Acknowledgment}

The authors are thankful to Bidhan Chandra Krishi Vishwavidalaya, Nadia, West Bengal for providing field and necessary laboratory facilities for conducting this research.

\section{References}

Arya, S. K. and B. K. Roy: Manganese induced changes in growth, chlorophyll content and antioxidants activity in seedlings of broad bean (Vicia faba L.). J. Environ. Biol., 32, 707-711 (2009).

Baishya, L. K., M. Kumar and D. C. Ghosh: Effect of different proportion of organic and inorganic nutrients on productivity and profitability of potato (Solanum tuberosum) varieties in Meghalaya hills. Indian J.Agron., 55, 230-234 (2010).

Chadha, S., S.S. Rana, Rameshwar and D.R. Chaudhary: Effect of split application of N, Kand FYM on the productivity of seed potatoes in cold desert region of H.P. Potato J., 34, 94-96 (2006).

Datta, J.K., M. Banerjee, S. Saha, S. Gupta and N.K. Mondal: Impact of 
combined exposure of chemical, fertilizer, bio-fertilizer and compost on growth, physiology and productivity of Brassica campestris in old alluvial soil. J. Environ. Bio., 30, 797-800 (2009).

Fekadu, A. : Effect of integrated soil amendment practices on growth and seed tuber yield of potato (Solanum tuberosum L.) at Jimma Arjo, Western Ethiopia. J. Nat. Sci. Res., 6, 1-26 (2016).

Gaur, A.C. : Organic manure - A basic input organic farming. Indian Farming, 51, 3-5 (2001).

Ghosh, P. K., R. Saha, J.J. Gupta, T. Ramesh, A. Das, T.D. Lama, G. C. Munda, J.S. Bordoloi, M.R. Verma and S. V. Ngachan: Long term effect of pastures on soil quality in acid soil of North-East India. Australian J. Soil Res., 47, 372-379 (2009).

Gomez, K.A. and A.A. Gomez: Statistical procedures for Agricultural Research. International Rice Research Institute Book, John Wiley and Sons, New York (1984).

Govindakrishnan, P.M. and V.S. Kushwah: Low input technology for potato production-The Potato. Mehta Publishers, New Delhi, India, pp.130-135(2003).

Hedge, D. M. and B.S. Dwivedi: Integrated nutrient supply and management as a strategy meet nutrient demand. Fertilizer News, 38, 49-50 (1993).

Islam Md. M., A. Sajeda, N.M. Majid, M. J. Ferdous and A. Shamshul: Integrated nutrient management for potato (Solanum tuberosum) in grey terrace soil (Aric Albaquipt). Australian J. Crop Sci., 7, 1235-1241 (2013).

Jackson, M.S.: Soil Chemical Analysis. Prentice Hall of India Pvt. Ltd., New Delhi. (1973).

Jat, L.K. and Y.V. Singh: Short-term effects of organic and inorganic fertilizers on soil properties and enzyme activities in rice production. Int.J.Curr.Microbiol.App.Sci., 6, 185-194 (2017).

Khurana, P. S. M. and P.S. Naik: The Potato: An overview. In the Potato Production and Utilization in Sub- tropics (Eds.: S. M. Paul Khurana, J.S. Minas and S.K. Pandey). Mehta Publication, New Delhi, p. 1-14 (2003).

Kumar, M., L.K. Baishaya, D.C. Ghosh, V.K. Gupta., S.K. Dubey, A. Das and D.P. Patel: Productivity and soil health of potato (Solanum tuberosum L.) field as influenced by organic manures, inorganic fertilizers and biofertilizers under high altitudes of Eastern Himalayas. J. Agric. Sci., 4, 223-234 (2012).

Kushwah, V.S., S.P. Singh and S.S. Lal: Effect of manures and fertilizers on potato (Solanum tuberosum) production. Potato J., 32, 157-158 (2005).

Manna, M. C., A. Swarup, R.H. Wanjari, Y.V. Singh, P.K. Ghosh, K.N. Singh, A.K. Tripathi and M.N. Saha: Soil organic matter in West Bengal inceptisol after 30 years of multiple cropping and fertilization. Soil Sci. Soc. Am. J., 70,121-129 (2006).

Mbogo, N. W., J.M. Kinama, C. Onyango and J.N. Kabira: Effect of inorganic fertilizer and cattle manure on growth and yield of two Kenyan potato varieties. Int. J. Agron. Agri. R., 10, 65-72 (2017).

Mondal, B., D. Subhaprada, D. Sethi and M. Banerjee: Effect of different nutrient management on growth and productivity of potato. Adv. Life Sci., 5, 2697-2702 (2016).

Mondal, S.S. and B. Sarkar: Effect of integrated nutrient management on the growth and productivity of potato (Solanum tuberosum). Environ. Eco., 235, 387-391 (2005).

Muhr, G.R., N.P. Dutta, S. H. Sankar, V.K. Laley and R.L. Donahue: Soil testing in India. U.S.A. for International Development Mission to India, New Delhi, p.229-311 (1965).

Najm, A. A., M.R. Haj Seyed Hadi, F. Fazeli, M. Taghi Darzi and R. Shamorady: Effect of utilization of organic and inorganic nitrogen source on the potato shoots dry matter, leaf area index and plant height, during middle stage of growth. Int. J. Biol. Bimole. Agricul. Food Biotechnol. Engin., 4, 852-855 (2010).

Praharaj, C.S., D. Kumar and R.C. Sharma: Extended summaries of the $2^{\text {nd }}$ International Congress on Balancing Food and Environmental security-a continuing challenge, IARI, New Delhi, pp. 232-333 (2002).

Singh, H., D. Mishra and N.M. Nahar: Energy use pattern in production agriculture of a typical village in Arid Zone India (Part I). Energy Conversion Mangt., 43, 275-286 (2002).

Tarafdar, J.C., K.P. Tripathi and M. Kumar: Organic Agriculture. Scientific Publisher, Jodhpur, p. 372 (2008).

Upadhayay, N. C. and J.P. Singh: The Potato (Production and Utilization in Sub-Tropics (Eds.: S. M. Paul Khurana, J.S. Minhas and S.K. Pandey). Mehta Publishers, India (2003).

Vidyavathi, D.G.S., H.B. Babalad, N.S. Hebsur, S.K. Gali, S.G. Patil and A.R. Alagawadi: Influence of nutrient management practices on crop response and economics in different cropping systems in a vertisol. Karnataka J. Agric. Sci., 24, 455-460 (2011).

Yadav, S.K., A.K. Srivastava and T.K. Bag: Effect of integrated nutrient management on production of seed tubers from true potato (Solanum tuberosum) seed. Indian J. Agron., 59, 646-650 (2014).

Yadav, S.K., S. Babu, M.K. Yadav, K. Singh, G.S. Yadav and S. Pal: A review of organic farming for sustainable agriculture in Northern India. Int. J. Agron., Vol. 2013, Article ID 718145, 1-8 (2013b).

Yadav, S.K., S. Babu, Y. Singh, M.K. Yadav, G.S. Yadav, S. Pal, R. Singh and K. Singh: Effect of organic nutrient sources on yield, nutrient uptake and soil biological properties of rice (Oryza sativa) cropping sequence. Indian J. Agron., 58, 70-75 (2013a).

Zaman, A., A. Sarkar, S. Sarkar and W.P. Devi: Effect of organic and inorganic sources of nutrients on productivity, specific gravity and processing quality of potato (Solanum tuberosum). Indian J. Agric., Sci., 81, 1137-1142 (2011). 